Article

\title{
In Vitro Observations of the Interactions between Pholiota carbonaria and Polytrichum commune and Its Potential Environmental Relevance
}

\author{
Daniel B. Raudabaugh ${ }^{1,2, *(D)}$, Daniel G. Wells ${ }^{1,3}$, Patrick B. Matheny ${ }^{4}$, Karen W. Hughes ${ }^{4}$ D, Malcolm Sargent ${ }^{5}$, \\ Teresa Iturriaga ${ }^{6}$ and Andrew N. Miller ${ }^{1}$ (D)
}

1 Illinois Natural History Survey, University of Illinois Urbana-Champaign, Champaign, IL 61820, USA; dgwells2@illinois.edu (D.G.W.); amiller7@illinois.edu (A.N.M.)

2 Department of Environmental Engineering, Duke University, Durham, NC 27708, USA

3 Department of Molecular and Cellular Biology, University of Illinois Urbana-Champaign, Champaign, IL 61820, USA

4 Department of Ecology and Evolutionary Biology, University of Tennessee, Knoxville, TN 37996, USA; pmatheny@utk.edu (P.B.M.); khughes@utk.edu (K.W.H.)

5 Department of Plant Biology, University of Illinois Urbana-Champaign, Champaign, IL 61820, USA; malcolms@life.illinois.edu

6 School of Integrative Plant Science, Cornell University, Ithaca, NY 14850, USA; ti14@cornell.edu

* Correspondence: raudaba2@illinois.edu; Tel.: +1-(570)-912-2345

check for

updates

Citation: Raudabaugh, D.B.; Wells, D.G.; Matheny, P.B.; Hughes, K.W.;

Sargent, M.; Iturriaga, T.; Miller, A.N. In Vitro Observations of the Interactions between Pholiota carbonaria and Polytrichum commune and Its Potential Environmental Relevance. Life 2021, 11, 518. https://doi.org/10.3390/ life11060518

Academic Editor: Laura Selbmann

Received: 30 April 2021

Accepted: 1 June 2021

Published: 3 June 2021

Publisher's Note: MDPI stays neutral with regard to jurisdictional claims in published maps and institutional affiliations.

Copyright: (c) 2021 by the authors. Licensee MDPI, Basel, Switzerland. This article is an open access article distributed under the terms and conditions of the Creative Commons Attribution (CC BY) license (https:/ / creativecommons.org/licenses/by/ $4.0 /)$.

\begin{abstract}
Wildfires play a critical role in maintaining biodiversity and shaping ecosystem structure in fire-prone regions, and successional patterns involving numerous plant and fungal species in post-fire events have been elucidated. Evidence is growing to support the idea that some post-fire fungi can form endophytic/endolichenic relationships with plants and lichens. However, no direct observations of fire-associated fungal-moss interactions have been visualized to date. Therefore, physical interactions between a post-fire fungus, Pholiota carbonaria, and a moss, Polytrichum commune, were visually examined under laboratory conditions. Fungal appressoria were visualized on germinating spores and living protonemata within two weeks of inoculation in most growth chambers. Appressoria were pigmented, reddish gold to braun, and with a penetration peg. Pigmented, reddish gold to braun fungal hyphae were associated with living tissue, and numerous mature rhizoids contained fungal hyphae at six months. Inter-rhizoidal hyphae were pigmented and reddish gold to braun, but no structures were visualized on mature gametophyte leaf or stem tissues. Based on our visual evidence and previous work, we provide additional support for $P$. carbonaria having multiple strategies in how it obtains nutrients from the environment, and provide the first visual documentation of these structures in vitro.
\end{abstract}

Keywords: agaricales; endophytes; fungal-bryophyte ecology; pyrophilous fungi; wildfire

\section{Introduction}

Wildfires play a critical role in shaping ecosystems, maintaining biodiversity, and influencing ecological processes in fire-prone regions [1]. Early post-fire colonizers include fire-associated fungal and bryophyte species that often occur in close spatial proximity [2-4]. Early colonizers are believed to be important in ecosystem recovery through nutrient retention, binding soil particles, and serving as mycorrhizal inoculants [2,3]. Unfortunately, there is a knowledge gap in our understanding of post-fire early colonizer life strategies, particularly with respect to post-fire fungi.

Post-fire fungi are categorized into two main categories based on their response to fruiting in burnt habitats [5]: (1) fruiting occurs only after a fire, and (2) fruiting can occur at any time, but fruiting is enhanced after a fire. Anthracobia spp., Ascobolus spp., Morchella exuberans Clowez, Hugh Sm. and S. Sm., Peziza echinospora P. Karst., Plicaria spp., Psathyrella 
pennata (Fr.) A. Pearson and Dennis, Pholiota carbonaria (Fr.) Singer, Pyronema spp., and Rhizina undulata Fr. are some species that require fire to fruit. Fungal species with enhanced fruit body production after a fire include Hygrocybe conica (Schaeff.) P. Kumm., Mycena galericulata (Scop.) Gray, Sphaerosporella spp., and Thelephora terrestris Ehrh. [5].

Similar to post-fire fungi, there are species of mosses and liverworts that rapidly colonize burnt areas after a forest fire. They are often the first species to colonize burnt substrates, especially after intense fires, and their role at the beginning of succession should not be underestimated. These include, but are not limited to, Bryum argenteum Hedw., B. sauteri Bruch and Schimp., Campylopus introflexus (Hedw.) Brid., Ceratodon purpureus (Hedw.) Brid., Funaria hygrometrica Hedw., Polytrichum juniperinum Hedw., and the postfire liverwort, Marchantia polymorpha L. [6,7]. Juvenile gametophytes of B. argenteum, C. purpureus, and F. hygrometrica typically appear around six weeks after a fire, whereas M. polymorpha typically appears after several months [8]. There is an apparent lack of knowledge concerning the colonization of bryophytes on burnt wood, which is an essential topic when planning forest restoration treatments that aim to increase biodiversity. In relation to P. carbonaria, basidiomata of this species start to appear about five months after a fire event and continue fruiting for at least 18 months [5], placing both fungal spores and maturing bryophytes in close temporal and spatial proximity.

In times between fire events, studies have indicated that some post-fire fungi remain in the soil as active saprobes [9] or dormant as spores or sclerotia [10,11]. Other post-fire fungi appear to associate as endophytes [12,13], mycorrhizae [14,15], or pathogens [16]. Recently, Matheny et al. 2018 [17] proposed the body snatchers hypothesis, suggesting that some post-fire fungi form endophytic and/or endolichenic relationships with bryophytes and lichens. In addition, Raudabaugh et al. [18] provided support for the body snatchers hypothesis based on published GenBank sequences [15,19-21] and culture-dependent and metagenomic culture-independent analyses. They detected many post-fire fungi from bryophyte, lichen, and club moss samples. Similarly, U'Ren et al. [19] stated that more than half of bryophyte and lichen endophytes within the Arizona fire-dominated forests belong to post-fire fungal taxa including Anthracobia, Geopyxis, and Pyronema, suggesting an important relationship between bryophytes and some post-fire fungi taxa.

Pholiota carbonaria (syn. P. highlandensis) is a member of the family Strophariaceae, order Agaricales, and is a well-known post-fire fungus [22]. It has a cosmopolitan distribution throughout the Americas, East Asia, and Europe [17]. This species has been inferred to form associations with vascular plant species (genera Pinus and Taxus), bryophytes, and lichens [17]. Pholiota carbonaria has been previously isolated into pure culture (as $P$. highlandensis [17]) from surface-sterilized P. commune Hedg. and identified as an endophyte from surface-sterilized tissues of Atrichum angustatum, Bryaceae sp., Cinclidium sp., Climacium americanum, Leucobryum sp., Lobaria quercizans Michx, P. commune, and Thuidium sp. [18], and as a saprobe [23]. Due to the ubiquitous range of P. commune and the post-fire fungus $P$. carbonaria, ease of growing both species in vitro, and solid evidence that these species interact in nature qualify this fungal-host combination as a suitable model to understand post-fire fungal-bryophyte interactions.

Therefore, although there is currently ample evidence to support that some pyrophilous fungi can associate with bryophytes, there is a lack of visual documentation as to the extent (structures and location) of these specific fungal-moss interactions. Consequently, this study aimed to visually document the physical interactions (structures produced) in vitro between a post-fire fungus, P. carbonaria, and the moss, P. commune, and discuss the environmental relevance of this interaction.

\section{Materials and Methods}

\subsection{Isolation/Sampling of Fungi}

We obtained P. carbonaria cultures from surface-sterilized moss tissues and from basidiomata collected from the Great Smoky Mountains National Park (Figure 1a,b). Tissues of several post-fire bryophytes were surface sterilized by washing in sterile distilled water 
followed by a $30 \mathrm{~s}$ immersion in $70 \%$ ethanol (EtOH), $30 \mathrm{~s}$ in 10\% Clorox (sodium hypochlorite), and $30 \mathrm{~s}$ in $95 \% \mathrm{EtOH}$ [13]. After surface sterilization, samples were placed on sterile paper towels to dry. Mosses were cut into small segments, including gametophyte and sporophyte tissues, where available and placed on malt extract agar (15 g Difco malt extract, $20 \mathrm{~g}$ Difco agar/liter) in $60 \mathrm{~mm}$ Petri dishes, sealed with Parafilm and incubated at room temperature. Cultures were examined every day for growth of fungal endophytes from moss fragments, and any observed endophytes were sub-cultured to new plates. To identify fungal endophytes, fungal cultures were sub-cultured to liquid potato dextrose broth and allowed to grow until sufficient tissue was available for DNA extraction. Cultured endophyte identities were confirmed through nucleotide analysis of the fungal internal transcribed spacer region (ITS) using the Basic Local Alignment Search Tool [24,25].

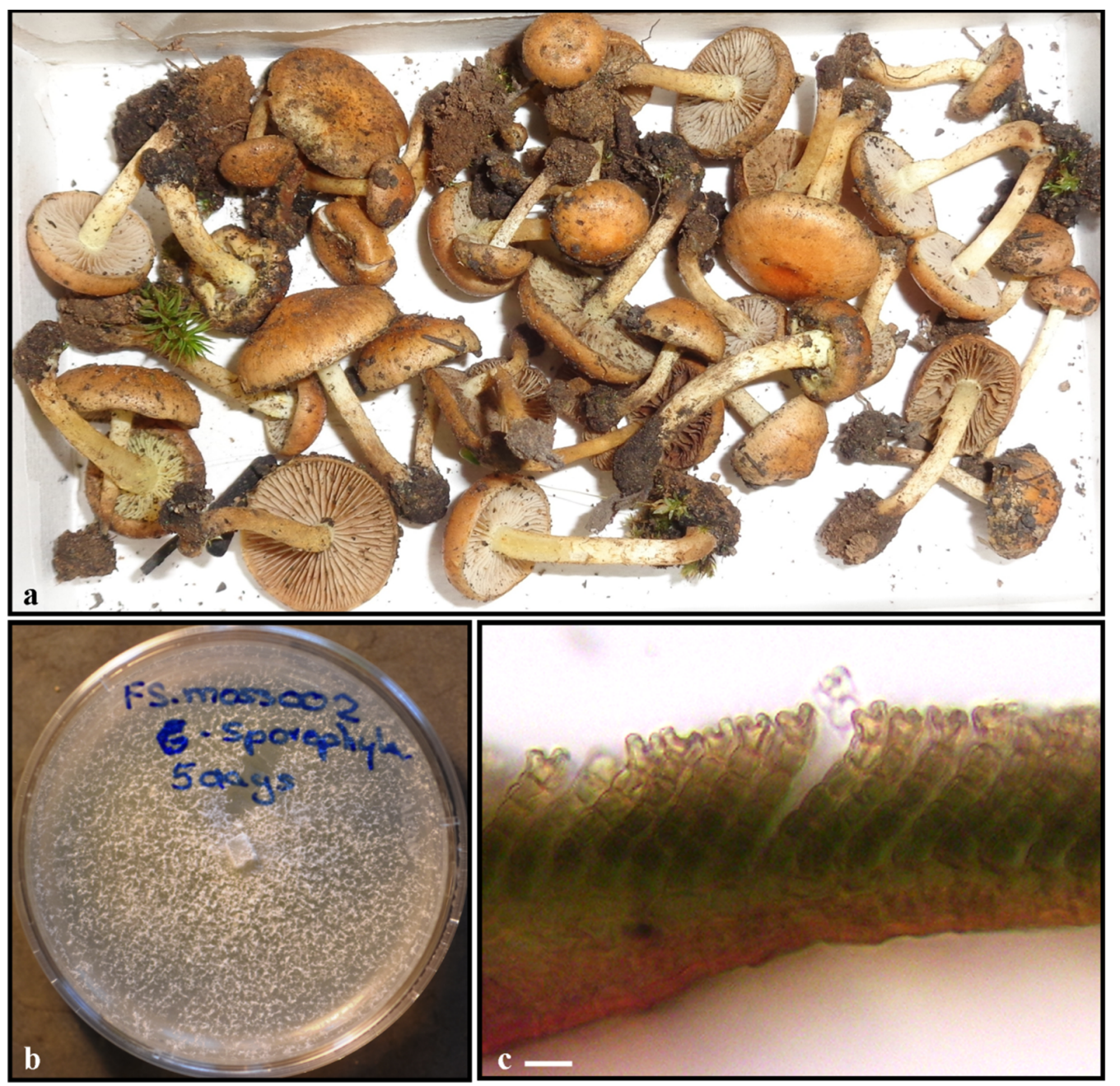

Figure 1. Pholiota carbonaria and Polytrichum commune. (a) P. carbonaria was collected in October 2017 from the Great Smoky Mountains National Park. Note several moss gametophytes in close proximity to the collected basidiomata. (b) P. carbonaria isolated from the moss $P$. commune in pure culture. (c) P. commune u-shaped terminal lamella cells of in vitro gametophyte. Scale bar $=20 \mu \mathrm{m}$.

\subsection{Growth Chamber Setup and Fungal Inoculation}

Modified BCD medium [26] was heated under constant stirring until agar was completely dissolved, and $\sim 25 \mathrm{~mL}$ of media was added to $72 \times 72 \times 100 \mathrm{~mm}$ transparent square vessels (SPL Incu Tissue). This comprised the growth chamber (Figure 2a). Growth chambers were capped with lids, covered with aluminum foil, and autoclaved at standard temperature and pressure. After cooling, the bottom of each growth chamber was wrapped with aluminum foil 1-2 cm high (Figure 2a). Growth medium modifications consisted of 
the following: trace elements were added by using orchid fertilizer (Miracle Gro ${ }^{\circledR}$ (Lowe's, Mooresville, NC, USA) mixed per manufacturer instructions and one $\mathrm{mL} \mathrm{L}^{-1}$ of this orchid fertilizer solution was added to the BCD medium before autoclaving. Ferrous sulfate was not added due to its inclusion within the orchid fertilizer.
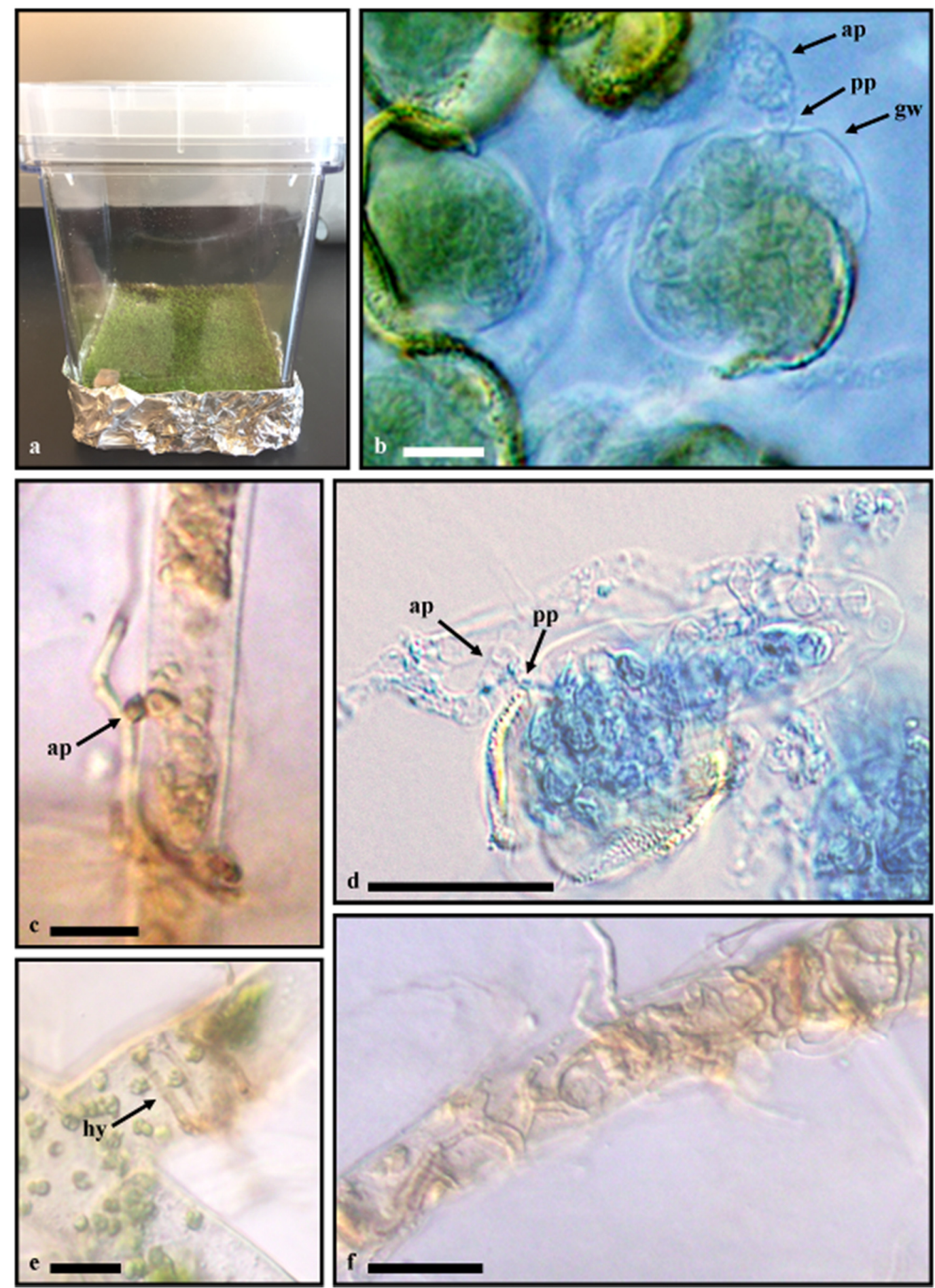

Figure 2. Associations of Pholiota carbonaria with Polytrichum commune. (a) Control growth chamber at three months; (b) fungal appressorium associating with germinating spore 14 days after inoculation; (c) appressorium attached to protonema at one month; (d) trypan blue stain showing continuous staining from appressorium into germinating spore, day 14 post-inoculation; (e) associated fungal hyphae with living tissue at two months; (f) mature rhizoids at six months. Scale bars $\mathbf{b}-\mathbf{f}=10 \mu \mathrm{m}$. ap = appressorium, $\mathrm{pp}=$ penetration $\mathrm{peg}, \mathrm{gw}=$ germinating spore cell wall, and hy = fungal hyphae. 
Polytrichum moss spores were obtained from Carolina Biological Supply (item \# 156661). Each growth chamber was inoculated with moss spores under a laminar flow hood. The outer surface of moss spore vials were wiped down with $100 \%$ ethanol before opening, Polytrichum spores were allowed to fall onto the medium surface in a fine layer, recapped, and set by a windowsill exposed to both partial direct and partial indirect light at $22{ }^{\circ} \mathrm{C}$. After one week, growth chambers containing Polytrichum spores were visually inspected for bacterial and fungal contamination. Four growth chambers were randomly selected, and one corner was inoculated with one $4 \times 4 \mathrm{~mm}$ agar plug containing actively growing P. carbonaria mycelia. This was repeated for 4 weeks to allow four different stages of Polytrichum development to be exposed to P. carbonaria. Negative controls consisted of growth chambers without Polytrichum spores and uninoculated Polytrichum spores. Polytrichum, species level identification, was determined at the end of the experiment to be P. commune, the most widely distributed Polytrichum species in the eastern United States [27], based on the $\mathrm{u}$-shaped terminal lamella cells of the gametophyte (Figure 1c).

\subsection{Microscopic Examination}

Light microscopic evaluation was conducted using an Olympus BX51 microscope with differential interference contrast (DIC) equipped with an Olympus DP22 camera. Images were captured and measured using Olympus cellSens standard software version 1.18 (Olympus Corporation, Tokyo, Japan). Each week a small piece of medium with germinated Polytrichum spores was excised and examined for the presence of fungal-host interactions. Staining procedures using lactophenol cotton blue, trypan blue, and acidified trypan were used in an attempt to visualize the resulting structures [28] better. Color was determined using Kornerup and Wanscher [29].

\subsection{Evaluation of Fungal Endophytic Association}

Six-month-old Polytrichum gametophytes from inoculated and uninoculated control growth chambers were surface sterilized following a modified version of [30]. In short, moss gametophytes were transferred to plastic cassettes, submerged in distilled water with forceful agitation to remove external medium for $30 \mathrm{~s}$, submerged for $10 \mathrm{~s}$ in $96 \% \mathrm{EtOH}$, $1 \mathrm{~min}$ in $\mathrm{NaOCl}$ solution ( $3 \%$ available $\mathrm{Cl}$ ), and $10 \mathrm{~s}$ in $96 \% \mathrm{EtOH}$ solution with a final rinse for $30 \mathrm{~s}$ in distilled water. All plastic cassettes were agitated throughout the entire surface sterilization process. Surface-sterilized gametophytes were placed onto malt extract agar (MEA) in $60 \mathrm{~mm}$ Petri plates, wrapped with Parafilm, incubated in the dark for 1-2 weeks, and periodically examined for fungal growth. Fungal colonies that grew out from the gametophytes were transferred to MEA plates.

\subsection{Post-In Vitro Fungal DNA Extraction, Sequencing, and Identity}

Fungal DNA was extracted by grinding fresh mycelium in $200 \mu \mathrm{L} \mathrm{0.5} \mathrm{M} \mathrm{NaOH}$. The extract was centrifuged at $16,873 \times g$ for $2 \mathrm{~min}$, and $5 \mu \mathrm{L}$ of the resulting supernatant was added to $495 \mu \mathrm{L} 100 \mathrm{mM}$ Tris-HCl buffered with $\mathrm{NaOH}$ to $\mathrm{pH}$ 8.5-8.9 (Tris-HCl-DNA extraction solution [31]). PCR was completed on a Bio-Rad PTC 200 thermal cycler. The total reaction volume was $25 \mu \mathrm{L}\left(12.5 \mu \mathrm{L}\right.$ GoTaq $^{\circledR}$ Green Master Mix (Promega, Madison, WI, USA), $1 \mu \mathrm{L}$ of each $10 \mu \mathrm{M}$ primer ITSIF and ITS4 [32,33], $3 \mu \mathrm{L}$ of the Tris-HCl-DNA extraction solution and $7.5 \mu \mathrm{L}$ DNA free water). Thermal cycle parameters consisted of an initial denaturation at $94{ }^{\circ} \mathrm{C}$ for $2 \mathrm{~min}$, followed by 30 cycles of $94{ }^{\circ} \mathrm{C}$ for $30 \mathrm{~s}, 55^{\circ} \mathrm{C}$ for $45 \mathrm{~s}$, $72{ }^{\circ} \mathrm{C}$ for $1 \mathrm{~min}$ with a final extension step of $72{ }^{\circ} \mathrm{C}$ for $10 \mathrm{~min}$. Gel electrophoresis (1\% TrisBorate- Ethylenediaminetetraacetic acid agarose gel stained with ethidium bromide) was used to verify the presence of a PCR product. Purification was completed using a Wizard ${ }^{\circledR}$ SV Gel and PCR Clean-Up System (Promega). A BigDye ${ }^{\circledR}$ Terminator 3.1 cycle sequencing kit (Applied Biosystems Inc., Foster City, CA, USA) was used to sequence the ITS in one direction using the ITS5 primer [32] on an Applied Biosystems 3730XL high-throughput capillary sequencer. Fungal isolate identity was confirmed through comparison to the pre-inoculation ITS sequence of $P$. carbonaria (GenBank number MT307288) [5]. 


\section{Results}

Microscopic evaluation of $P$. commune germinating spores showed numerous hyphae of $P$. carbonaria in close proximity to germinating spores and protonemata. Hyphae of P. carbonaria had prominent clamp connections. No noticeable difference with inoculation time was perceived. Fungal appressoria were visualized on germinating spores and living protonemata (Figure $2 \mathrm{~b}-\mathrm{d}$ ) within two weeks of inoculation in most growth chambers. Appressoria were pigmented, reddish gold to braun, 7.5-8.0 $\times 6.0-6.5 \mu \mathrm{m}$, with the penetration peg 1.5-2.0 × 1.5-1.8 $\mu \mathrm{m}$ (Figure 2b,c). Pigmented, reddish gold to braun fungal hyphae were associated with living tissue (Figure 2e), and numerous mature rhizoids contained fungal hyphae at six months (Figure 2f). Inter-rhizoidal hyphae were pigmented, reddish gold to braun, and 2-2.5 $\mu \mathrm{m}$ wide (Figure $2 \mathrm{f}$ ). No structures were visualized on mature gametophyte leaf or stem tissues. Pholiota carbonaria was isolated from surfacesterilized six-month-old gametophytes, and the nBLAST analysis of the ITS rDNA region of the isolate was virtually identical (one base pair difference) original inoculants. No fungi were observed within negative controls and P. carbonaria was not isolated from uninoculated spore controls. In two months, several fruit body initials and mature P. carbonaria basidiomata were produced with viable basidiospores capable of generating new cultures (Figure 3).
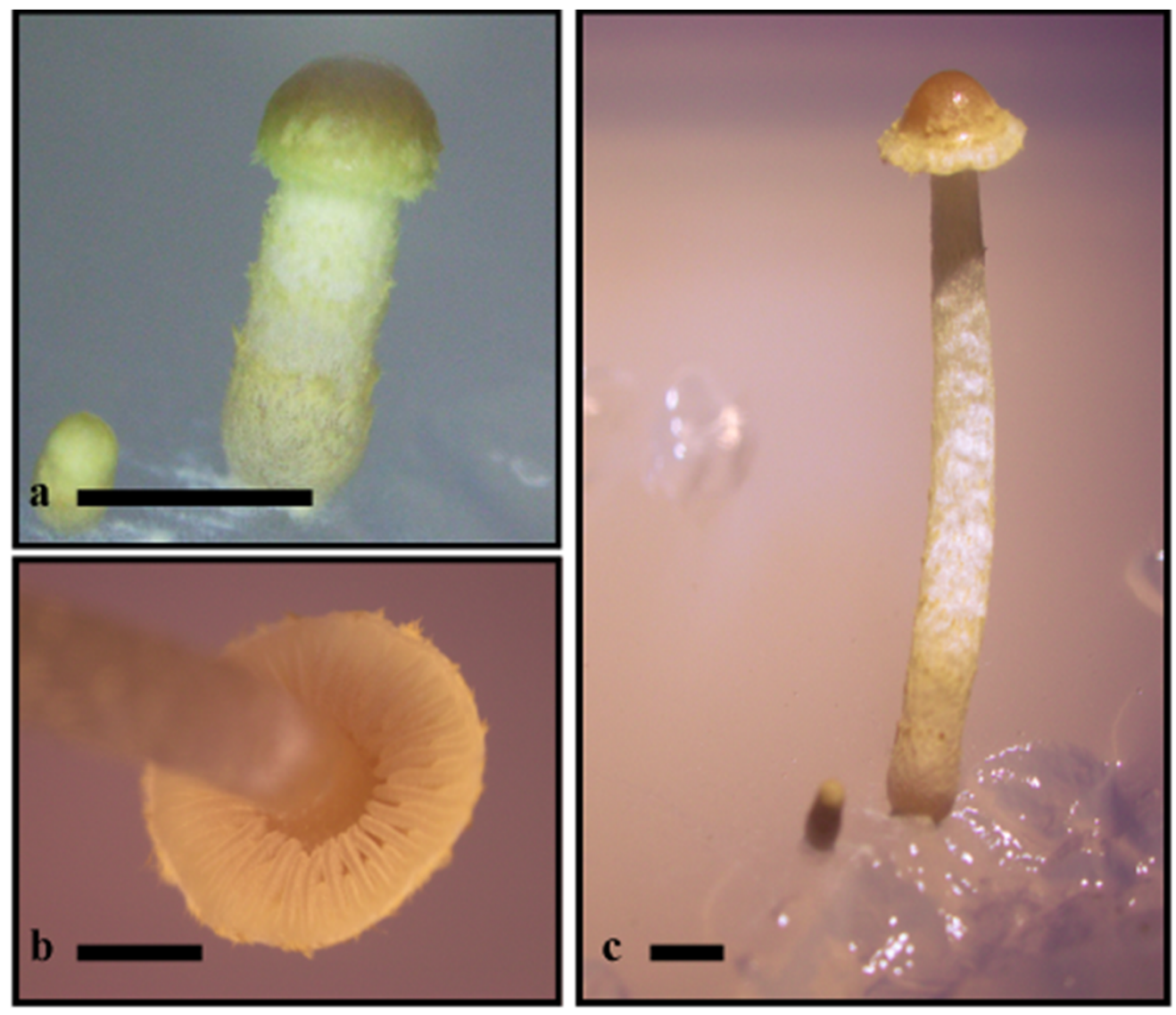

Figure 3. In vitro Pholiota carbonaria fruit body initials and mature basidiomata at two months postinoculation. (a) Initial and developing basidiome. (b) Exposed lamellae. (c) Initial and basidiome. Scale bars: $\mathrm{A}-\mathrm{C}=5 \mathrm{~mm}$.

\section{Discussion}

We have documented that $P$. carbonaria can form structures associated with living germinating moss spores (Figure $2 \mathrm{~b}, \mathrm{~d}$ ) and protonema via appressoria (Figure $2 \mathrm{c}$ ) and penetration pegs (Figure $2 \mathrm{~b}, \mathrm{~d}$ ) and can colonize mature rhizoids of $P$. commune in vitro (Figure 2f) but with unapparent and asymptomatic infection. This association is believed 
to be endophytic based on definitions outlined by Wilson [34] which suggested that all endophytes are either commensals or parasites since they derive all their nutrients from the host but cause unapparent and asymptomatic infection and have at least some of their life cycle inside plant tissues. This is in contrast to pathogens that cause apparent and symptomatic infections. We also documented the production of mature basidiomata of $P$. carbonaria in vitro (Figure $3 \mathrm{a}-\mathrm{c}$ ) for the first time. Since numerous cultures of $P$. carbonaria held at the University of Tennessee did not fruit in culture, even after extended time, it is tempting to suggest that fruiting may be affected by the presence of moss gametophytes but further investigation is needed. It is possible that the colonization of young gametophyte structures and mature rhizoids may represent an opportunistic in vitro association and not necessarily an in vivo endophytic relationship. However, taking into account all the data collected thus far by various authors, we believe there is ample support to believe the fungal-host interactions documented here represent what can occur in nature.

Pholiota carbonaria has been previously isolated from many bryophyte species (discussed below) and was found in a large number (42\%, 16 of 38 samples) of surface-sterilized non-necrotic moss and lichen tissues [18]. Although fungal-bryophyte associations were thought to be uncommon, this is now believed to be a misconception. Because of the unique morphological and physiological makeup of bryophytes, Davey and Currah [35] suggest further study is needed to determine if fungal-moss interactions are similar and as common as fungal-vascular plant interactions.

The historical understanding of fungal-moss associations appears to vary within the literature. Pressel et al. [36] reported that fungal-moss symbiotic relationships have not been demonstrated and that most fungal structures are confined to dead or senescing host cells. By contrast, Zhang and Guo [37] investigated arbuscular mycorrhizal structures in mosses and found vesicles, intracellular hyphal coils, and intercellular aseptate hyphae in living stems and leaves but not rhizoids of mosses. Zhang and Guo [37] also concluded that the presence of these structures was not evidence for a mutualistic symbiosis; however, there are other associations beyond mutualistic symbiosis that may represent a biotrophic association. Interestingly, six genera within the Ascomycota family Pyronemataceae, of which some species are found in burned areas, are obligate symbionts with bryophytes $[20,38]$. They produce hyphae that are attached to living rhizoids via appressoria with intracellular haustoria [39]. Previous research has suggested that these fungi are likely to obtain some nutrients from their host $[20,40]$.

Species within the Basidiomycota have also demonstrated the ability to form associations with bryophytes, including parasitic/pathogenic [41], and saprobic [42] relationships. Although parasitic/pathogenic interactions occur, the funal-host interactions vary [35]. Appressoria are common in vascular plant-fungal biotrophic interactions [43], but although not absent, they are less common in bryophyte pathogenic fungi [35], which form penetration pegs and use extracellular enzymes. Redhead [41] investigated the interactions between Galerina paludosa (Fr.) Kühner and Sphagnum capillifolium (Ehrh.) Hedw. (formally, Sphagnum capillaceum (Weiss) Schrank). Moreover, it was concluded that they form a parasitic relationship. Redhead [41] visualized peg-like haustoria at day 14, and by one month, he noted infection of cells of the protonema, rhizoids, and prothallus, in addition to hyphae growing through dead cells [41]. Further evidence of biotrophic interactions between fungi and bryophytes were completed by Korotkin et al. [44]. They found stable isotopic evidence providing direct evidence for numerous biotrophic interactions between fungi in the order Hymenochaetales and bryophytes.

Our study visualized what appeared to be appressoria with penetration pegs (Figure $2 b-d$ ) occurring on germinating spores and young gametophytes, suggesting an initial parasitic relationship similar to that seen by [41] but there was no evidence of necrosis. Davey and Currah [35] suggested that since G. paludosa infects only the initial filaments from germinating spores, this relationship may be a pioneering life-history strategy or that G. paludosa attacks immature gametophytes before the host can mount a resistance. Based on the current visual evidence and previous work, $P$. carbonaria has plasticity in its nutritional 
relationship [34] with P. commune, which is not uncommon among fungal species [45]. The time line of and structures visualized in our study are similar to what has been reported for G. paludosa but with unapparent and asymptomatic infection. Furthermore, P. carbonaria is also likely saprobic within the dead tissue layers through the invasion of dead rhizoids over time and is capable of growing independently in vitro on malt extract and potato dextrose $[5,18]$. Although no infection in mature leaf and stem tissues was visually evident in this study, P. carbonaria was previously isolated from surface-sterilized non-necrotic leaf and stem tissues from several moss species.

\section{Environmental Relevance}

Fungal-moss associations may be common within the genus Pholiota. Chen et al. [46] detected two unidentified species of Pholiota from eastern North Carolina from culturedependent studies of the moss Dicranum scopiarum Hedw. ITS sequence data of these Pholiota isolates indicated that they were P. castanea, another post-fire Pholiota [17] and P. spumosa, a non-post-fire species of Pholiota. Raudabaugh et al. [18] isolated several cultures of $P$. carbonaria from surface-sterilized moss samples collected from recently burned sites in the Great Smoky Mountains National Park. The moss species from which these isolates were obtained included one fire-response moss, Funaria hygrometrica Hedw., and several common moss species such as Ceratodon purpureus (Hedw.) Brid., Ditrichum pallidum (Hedw.) Hampe, and P. commune. Another species, Pholiota castanea, was also identified from Atrichum angustatum (Brid.) Bruch and Schimp. [18]. Pholiota peleae E. Horak and Desjardin was described from Hawaii, and although not a post-fire Pholiota species, this species was initially described from bryophyte covered bark of living or dead Metrosideros polymorpha Gaudich [43] in addition to trunks of Cibotium glaucum (Sm.) Hook. and Arn. (a tree fern). Pholiota henningsii (Bres.) P.D. Orton is considered sphagnicolous, inhabiting or growing on Sphagnum, and is found rarely in several European countries [42]. It is believed that this Pholiota species likely break down lignin-like polymers and is not considered to parasitize Sphagnum species [42]. Finally, although not a Pholiota-bryophyte interaction, several Pholiota species were found in biological soil crusts (composed of fungi, algae, and cyanobacteria) in glacier forelands in Southern Norway [47], suggesting that Pholiota species have many life-history strategies that allow them to occupy a wide variety of poor nutrient habitats.

These previous studies and our current visual confirmation provide additional evidence that some fire-associated and non-post-fire species of Pholiota associate with mosses in nature. Notably, the broad range of moss species that $P$. carbonaria and other fire-associated fungi have been identified with in nature, along with the current in vitro observations of this association, suggest that the fungi-moss interaction may provide a more favorable environment (consistent source of nutrients, nitrogen, leachate, and moisture) than the surrounding soil. Depending on the fire intensity, burnt soil is low in some nutrients and has altered soil physical properties [48], including reducing the shallow organic matter layer, nitrogen, and water holding capacity. Interestingly, De Las Heras et al. [3] demonstrated that total nitrogen levels under bryophyte turfs were higher than the surrounding soil, which may be beneficial for fungal growth if soil nitrogen levels are insufficient postfire event. In addition, the ability to colonize both fire-associated mosses and later-stage successional moss species would provide the same long-term life strategy.

In summary, based on visual evidence and previous work, we show that P. carbonaria can form appressoria with penetration pegs, and invade mature rhizoid in vitro on $P$. commune and suggest that this post-fire species has multiple strategies in how it obtains nutrients from the environment. Future analyses of stable carbon and nitrogen signatures would be of value in fully understanding the nutritional relationship, electron microscopy visualization would be beneficial in further refining the interactions between $P$. carbonaria and $P$. commune, and a long-term study is needed to determine the temporal stability of this association. Although additional research is needed to understand this relationship fully, this study suggests that early post-fire colonizers may have more interconnected life 
histories than previously thought, which is essential when considering the contribution of post-fire fungi and bryophytes to post-forest fire system recovery.

Author Contributions: Conceptualization, D.B.R. and D.G.W.; data curation, A.N.M.; formal analysis, D.B.R.; funding acquisition, P.B.M., K.W.H. and A.N.M.; investigation, D.B.R.; methodology, D.B.R., D.G.W. and A.N.M.; resources, P.B.M., K.W.H. and A.N.M.; supervision, D.B.R. and A.N.M.; visualization, D.B.R., D.G.W. and A.N.M.; writing—original draft, D.B.R., D.G.W., P.B.M., K.W.H., M.S., T.I. and A.N.M.; writing—review and editing, D.B.R., D.G.W., P.B.M., K.W.H., M.S., T.I. and A.N.M. All authors have read and agreed to the published version of the manuscript.

Funding: This study was supported by awards from the National Science Foundation for "Collaborative Research: A Survey of Post-Fire Ascomycete and Basidiomycete Fungi in an Eastern Deciduous Forest" to the University of Tennessee (DEB 1733750) and the University of Illinois (DEB 1733854). In addition, this study was supported in part by the Schmidt Science Fellows, in partnership with the Rhodes Trust. Lastly, we thank Paul Super, Science Coordinator at the Great Smoky Mountains National Park, for the collection permit (study GRSM-01294, permit GRSM-2017-SCI-1294).

Institutional Review Board Statement: Not applicable.

Informed Consent Statement: Not applicable.

Data Availability Statement: Data are available upon request.

Conflicts of Interest: The authors declare no conflict of interest. The funders had no role in the design of the study; in the collection, analyses, or interpretation of data; in the writing of the manuscript, or in the decision to publish the results.

\section{References}

1. He, T.; Lamont, B.B.; Pausas, J.G. Fire as a key driver of Earth's biodiversity. Biol. Rev. 2019, 94, 1983-2010. [CrossRef]

2. Claridge, A.W.; Trappe, J.M.; Hansen, K. Do fungi have a role as soil stabilizers and remediators after forest fire? For. Ecol. Manag. 2009, 257, 1063-1069. [CrossRef]

3. Heras, J.D.L.; Herranz, J.M.; Guerra, J. The role of bryophytes in the nitrogen dynamics of soils affected by fire in Mediterranean forests (southeastern Spain). Écoscience 1996, 3, 199-204. [CrossRef]

4. Ryömä, R.; Laaka-Lindberg, S. Bryophyte recolonization on burnt soil and logs. Scand. J. For. Res. 2005, 20, 5-16. [CrossRef]

5. Hughes, K.W.; Matheny, P.B.; Miller, A.N.; Petersen, R.H.; Iturriaga, T.M.; Johnson, K.D.; Methven, A.S.; Raudabaugh, D.B.; Swenie, R.A.; Bruns, T.D. Pyrophilous fungi detected after wildfires in the Great Smoky Mountains National Park expand known species ranges and biodiversity estimates. Mycologia 2020, 112, 677-698. [CrossRef]

6. Duncan, D.; Dalton, P. Recolonisation by bryophytes following fire. J. Bryol. 1982, 12, 53-63. [CrossRef]

7. Bradbury, S. Response of the post-fire bryophyte community to salvage logging in boreal mixedwood forests of northeastern Alberta, Canada. For. Ecol. Manag. 2006, 234, 313-322. [CrossRef]

8. Lisiewska, M. Macrofungi on special substrates. In Fungi in Vegetation Science; Winterhoff, W., Ed.; Kluwer Academic Publishers: Dordrecht, The Netherlands, 1992; pp. 151-182.

9. Warcup, J.H.; Baker, K.F. Occurrence of Dormant Ascospores in Soil. Nat. Cell Biol. 1963, 197, 1317-1318. [CrossRef]

10. Jalaluddin, M. Studies on Rhizina undulata: I. Mycelial growth and ascospore germination. Trans. Br. Mycol. Soc. 1967, 50, 449-459. [CrossRef]

11. Baar, J.; Horton, T.R.; Kretzer, A.M.; Bruns, T.D. Mycorrhizal colonization of Pinus muricata from resistant propagules after a stand-replacing wildfire. New Phytol. 1999, 143, 409-418. [CrossRef]

12. Baynes, M.; Newcombe, G.; Dixon, L.; Castlebury, L.; O’Donnell, K. A novel plant-fungal mutualism associated with fire. Fungal Biol. 2012, 116, 133-144. [CrossRef]

13. Davey, M.L.; Heegaard, E.; Halvorsen, R.; Kauserud, H.; Ohlson, M. Amplicon-pyrosequencing-based detection of compositional shifts in bryophyte-associated fungal communities along an elevation gradient. Mol. Ecol. 2012, 22, 368-383. [CrossRef]

14. Egger, K.N.; Paden, J.W. Biotrophic associations between lodgepole pine seedlings and postfire ascomycetes (Pezizales) in monoxenic culture. Can. J. Bot. 1986, 64, 2719-2725. [CrossRef]

15. Vrålstad, T.; Holst-Jensen, A.; Schumacher, T. The postfire discomycete Geopyxis carbonaria (Ascomycota) is a biotrophic root associate with Norway spruce (Picea abies) in nature. Mol. Ecol. 1998, 7, 609-616. [CrossRef]

16. Weir, J.R. Observations on Rhizina inflata. J. Agric. Res. 1915, 4, 93-97. [CrossRef]

17. Matheny, P.B.; Swenie, R.; Miller, A.N.; Petersen, R.H.; Hughes, K.W. Revision of pyrophilous taxa of Pholiota described from North America reveals four species-P. brunnescens, P. castanea, P. highlandensis, and P. molesta. Mycologia 2018, 110, 997-1016. [CrossRef] [PubMed]

18. Raudabaugh, D.B.; Matheny, P.B.; Hughes, K.W.; Iturriaga, T.; Sargent, M.; Miller, A.N. Where are they hiding? Testing the body snatchers hypothesis in pyrophilous fungi. Fungal Ecol. 2020, 43, 100870. [CrossRef] 
19. U’Ren, J.M.; Lutzoni, F.; Miadlikowska, J.; Laetsch, A.D.; Arnold, A.E. Host and geographic structure of endophytic and endolichenic fungi at a continental scale. Am. J. Bot. 2012, 99, 898-914. [CrossRef] [PubMed]

20. Tedersoo, L.; Arnold, A.E.; Hansen, K. Novel aspects in the life cycle and biotrophic interactions in Pezizomycetes (Ascomycota, Fungi). Mol. Ecol. 2013, 22, 1488-1493. [CrossRef]

21. Wang, X.H.; Hahtinen, S.; Hansen, K. Multilocus phylogenetic and coalescent-based methods reveal di-lemma in generic limits, cryptic species, and a prevalent intercontinental disjunct distribution in Geopyxis (Pyronemataceae s. 1., Pezizomycetes). Mycologia 2016, 108, 1189-1215.

22. Legg, A. Fire-site agarics. Mycologia 1992, 6, 145-149. [CrossRef]

23. Hobbie, E.A.; Hofmockel, K.; van Diepen, L.T.; Lilleskov, E.A.; Ouimette, A.P.; Finzi, A.C. Fungal carbon sources in a pine forest: Evidence from a 13C-labeled global change experiment. Fungal Ecol. 2014, 10, 91-100. [CrossRef]

24. Altschul, S.F.; Gish, W.; Miller, W.; Myers, E.W.; Lipman, D.J. Basic local alignment search tool. J. Mol. Biol. 1990, 215 , 403-410. [CrossRef]

25. Schoch, C.L.; Seifert, K.A.; Huhndorf, S.; Robert, V.; Spouge, J.L.; Levesque, C.A.; Chen, W.; Fungal Barcoding Consortium. Nuclear ribosomal internal transcribed spacer (ITS) region as a universal DNA barcode marker for Fungi. Proc. Natl. Acad. Sci. USA 2012, 109, 6241-6246. [CrossRef] [PubMed]

26. Cove, D.J.; Perroud, P.-F.; Charron, A.J.; McDaniel, S.F.; Khandelwal, A.; Quatrano, R.S. Culturing the Moss Physcomitrella patens. Cold Spring Harb. Protoc. 2009, 2009, 5136. [CrossRef] [PubMed]

27. Drda, G.S.; Wyatt, R. Genetic Variation in the Common Hair-Cap Moss, Polytrichum commune. Syst. Bot. 1990, 15, 592. [CrossRef]

28. Barrow, J.R.; Aaltonen, R.E. A staining method for systemic endophyte fungi in plants. In Emerging Concepts in Plant Health Management; Lartey, R.T., Caesar, A.J., Eds.; Research Signpost: Kerala, India, 2004; pp. 61-67.

29. Kornerup, A.; Wanscher, J.H. Taschenlexikon der Farben; Musterschmidt Verlag: Zürich, Switzerland, 1961.

30. Petrini, O. Taxonomy of endophytic fungi in aerial plant tissues. In Microbiology of the Phyllosphere; Fokkema, N.J., van den Heuvel, J., Eds.; Cambridge University Press: New York, NY, USA, 1986; pp. 175-187.

31. Osmundson, T.W.; Eyre, C.A.; Hayden, K.M.; Dhillon, J.; Garbelotto, M.M. Back to basics: An evaluation of NaOH and alternative rapid DNA extraction protocols for DNA barcoding, genotyping, and disease diagnostics from fungal and oomycete samples. Mol. Ecol. Resour. 2013, 13, 66-74. [CrossRef]

32. White, T.J.; Bruns, T.; Lee, S.; Taylor, J. Amplification and direct sequencing of fungal ribosomal RNA genes for phylogenetics. In PCR Protocols: A Guide to Methods and Applications; Innis, M., Gelfand, D., Shinsky, J., White, T., Eds.; Academic Press: New York, NY, USA, 1990; pp. 315-322.

33. Gardes, M.; Bruns, T.D. ITS primers with enhanced specificity for basidiomycetes-Application to the identification of mycorrhizae and rusts. Mol. Ecol. 1993, 2, 113-118. [CrossRef]

34. Wilson, D. Endophyte: The Evolution of a Term, and Clarification of Its Use and Definition. Oikos 1995, 73, 274. [CrossRef]

35. Davey, M.L.; Currah, R. Interactions between mosses (Bryophyta) and fungi. Can. J. Bot. 2006, 84, 1509-1519. [CrossRef]

36. Pressel, S.; Bidartondo, M.I.; Ligrone, R.; Duckett, J.G. Fungal symbioses in bryophytes: New insights in the Twenty First Century. Phytotaxa 2010, 9, 238-253. [CrossRef]

37. Zhang, Y.; Guo, L.-D. Arbuscular mycorrhizal structure and fungi associated with mosses. Mycorrhiza 2007, 17, 319-325. [CrossRef]

38. Ptaszyńska, A.; Mułenko, W.; Żarnowiec, J. Bryophytes microniches inhabited by microfungi. Ann. UMCS Biol. 2009, 64, 35-43. [CrossRef]

39. Do“bbeler, P. Biodiversity of bryophilous ascomycetes. Biodivers. Conserv. 1997, 6, 721-738. [CrossRef]

40. Hansen, K.; Perry, B.A.; Dranginis, A.W.; Pfister, D.H. A phylogeny of the highly diverse cup-fungus family Pyronemataceae (Pezizomycetes, Ascomycota) clarifies relationships and evolution of selected life history traits. Mol. Phylogenetics Evol. 2013, 67, 311-335. [CrossRef]

41. Redhead, S.A. Parasitism of bryophytes by agarics. Can. J. Bot. 1981, 59, 63-67. [CrossRef]

42. Holec, J.; Kucera, T.; Moreau, P.-A.; Corriol, G.; Soldán, Z. Habitat preferences of Pholiota henningsii (Fungi, Strophariaceae), rare species of relict mires. Nova Hedwig. 2014, 98, 51-77. [CrossRef]

43. Agrios, G.N. Plant Pathology, 4th ed.; Academic Press: New York, NY, USA, 1997.

44. Korotkin, H.B.; Swenie, R.A.; Miettinen, O.; Budke, J.M.; Chen, K.-H.; Lutzoni, F.; Smith, M.E.; Matheny, P.B. Stable isotope analyses reveal previously unknown trophic mode diversity in the Hymenochaetales. Am. J. Bot. 2018, 105, 1869-1887. [CrossRef]

45. Wrzosek, M.; Ruszkiewicz-Michalska, M.; Sikora, K.; Damszel, M.; Sierota, Z. The plasticity of fungal interactions. Mycol. Prog. 2017, 16, 101-108. [CrossRef]

46. Chen, K.-H.; Liao, H.-L.; Arnold, A.E.; Bonito, G.; Lutzoni, F. RNA-based analyses reveal fungal communities structured by a senescence gradient in the moss Dicranum scoparium and the presence of putative multi-trophic fungi. New Phytol. 2018, 218, 1597-1611. [CrossRef]

47. Borchhardt, N.; Baum, C.; Thiem, D.; Köpcke, T.; Karsten, U.; Leinweber, P.; Hrynkiewicz, K. Soil microbial phosphorus turnover and identity of algae and fungi in biological soil crusts along a transect in a glacier foreland. Eur. J. Soil Biol. 2019, 91, 9-17. [CrossRef]

48. DeBano, L.F. The Effects of Fire on Soil Properties; United States Department of Agriculture, Forest Service, General Technical Report; INT-280: Fort Collins, CO, USA, 1991; pp. 151-156. 